\title{
Working their way to school completion: a snapshot of School-Based Apprenticeships and Traineeships for young Australians
}

Malgorzata Klatt ${ }^{\mathrm{a} *}$, Kira Clarke ${ }^{\mathrm{a}}$, Nicky Dulfer ${ }^{\mathrm{b}}$

${ }^{\mathrm{a}}$ Centre for Vocational and Educational Policy, Melbourne Graduate School of Education, The University of Melbourne, 100 Leicester St, Carlton, Victoria, Australia

${ }^{\mathrm{b}}$ Melbourne Graduate School of Education, The University of Melbourne, 100 Leicester St, Carlton, Victoria, Australia

This paper highlights troubling patterns within the Australian School-based Apprenticeships and Traineeships (SBATs) by analysing statistical data of 21,000 of 15 to 19 year old apprenticeship/traineeship learners engaged in Vocational Education and Training in School (VETiS). It confirms the alignment of social groups to certain qualification fields and levels and provides a compelling picture of the learner profile of SBAT including the type of occupations and qualifications being undertaken at school level. In a complex policy environment, where VET in Schools has been assigned the important task of preparing "workforce job-ready" students (Birmingham 2015) for the "high skill and high earning roles our economy demands" (Ley 2014), we argue that the SBAT pathway is not yet adequate to meet these high expectations. It is not an effective apprenticeship pathway as it potentially 'locks-in' already disadvantaged young people to precarious pathways, and reinforces the nature of an already highly gender-segregated Australian labour market. The paper helps to focus attention on endemic weaknesses in the Australian VET system that serve to entrench disadvantage in Australian society.

Keywords: SBAT, VETiS, Employment-based pathways, retention, disadvantage.

Acknowledgements: This work was supported by the 2014 Melbourne Graduate School of Education Seed Funding.

\footnotetext{
*Corresponding author. Email: klattm@unimelb.edu.au
} 


\section{Introduction}

Apprenticeships were a key mechanism of skill development throughout the preindustrial ages. In the modern era, their conditions, practices and regulatory frameworks have changed as a result of industrial revolution, the emergence of a market economy and growing global exchanges. In the past, apprenticeships were seen as a way of linking moral and safe upbringing with skills development of an individual assigned to a master. More recently, apprenticeships have been positioned as an essential ingredient of an efficient education system as they secure qualifications, enable workforce entry and increase a country's ability to compete internationally.

In Australia, within the last three decades a range of policy reforms and institutional re-arrangements have been introduced to 'ensure that all Australian school students acquire the knowledge and skills to participate effectively in society and employment in a globalised economy' (COAG 2008, 1). These reforms have coincided with increased secondary school completion targets, which are seen by Australian state and territory governments as an important policy goal (COAG 2008). Retention and engagement strategies have been increasingly focused on the skilling of young people already in high school, in line with identified skill shortages. Australian School-based Apprenticeships and Traineeships (SBATs) are one of the pathways within the Australian Vocational Education and Training (VET) landscape which is used to improve the transition of young people in to work (Clarke 2013). The commencement of an apprenticeship or traineeship at school enables young people to begin their occupational training program. In the Australian system, apprenticeships are offered in traditional trade occupations (e.g. automotive mechanic or hairdressing). As apprenticeships in these traditional trade areas are generally of four years duration; the apprenticeship continues, in a full-time capacity, once the young person completes high school. Australian traineeships are generally only 2 years in duration and provide training in mostly non-trade occupations (e.g. retail or recreation). There are currently over 20,000 young people involved in SBATs. There are also a number of policy initiatives proposed by Federal (Ley 2014, 1 July), and State (Queensland Government 2014; Johnston and Smethurst 2014) governments aimed at increasing the number of young people undertaking SBATs, as 'school-based apprenticeships provide the most direct pathway between school and work' (Ley 2014, 1 July). However, there is limited empirical evidence available which demonstrates the effectiveness of this pathway in building solid employment foundations. Researchers have also highlighted the need for further research regarding the success of 
school-based training that goes beyond measuring the completion rates and focuses on understanding the complexity of experiences by those young people negotiating school and work environment (Taylor, Lehmann, and Raykov 2014). Establishing the profile details of the students who take up the school-based training may provide an important insight into the conditioning factors these students and programs face.

Drawing on current research investigating the challenges of apprenticeship systems, this paper seeks to build a detailed illustration of the SBAT learner profile and the type of occupations and qualifications being undertaken in schools. The purpose of the analysis is to identify who is undertaking SBATs, where they live, which industry areas they are studying and the qualifications they are undertaking. This information will allow us to establish the main equity and possible policy challenges for developing successful school-based apprenticeship systems that improve school transitions for young people, especially those from disadvantaged backgrounds.

Firstly, we frame the analysis by identifying characteristics of the Australian youth transition system within the international context. Then we discuss the current skill requirements in Australian labour market and explain the Australian school-based training system and its challenges. The quantitative analysis which follows focuses on establishing the current demographic data related to SBATs and their selected field of study and qualification levels. The findings section focuses on the problematic areas of socio-economic distribution of SBAT learners, the highly gender segregated SBAT take-up as well as the dominance of four low-level qualification fields of study and their possible impact on labour market outcomes.

\section{The challenges of youth transition systems}

There has been extended research done over the years on youth transition systems or 'regimes' (Gallie and Paugam 2000, Pohl and Walther 2007, Raffe 2012, Verdier 10-12 September, 2009, Walther and Stauber 2002). Contemporary patterns of high youth unemployment, precarious jobs and enduring social disadvantage continue to motivate research in this field. There is an urgent need to address these educational and labour market inequalities before 'the pain and repercussions become explosive' (Standing 2011, xi). The international literature on youth transitions argues that the relationships between education, the labour market and other societal institutions are determined by distinct 'national logics' (Raffe 2012) or 'regimes' (Gallie and Paugam 2000, Pohl and Walther 2007, Raffe 2003, 2012, Verdier 10-12 September, 2009, Walther and Stauber 2002). Similarly, Bosch and 
Charest (2008) argue that we cannot understand developments in approaches to education and training without analysing structural and institutional relations in education and the labour market, and how these support skill formation. Iannelli and Raffe (2007), in their seminal article on the transition from vocational education to work, distinguished two ideal types of transition systems, which are based on the link between vocational education and employment. Walther and Stauber (2002) argue that only an integrated approach combines systemic and 'subjective' criteria of social integration may help policy-makers by enabling more effective transitions from youth to adulthood. The authors suggest that any reforms to education systems need to be implemented with regard to the local labour markets as well as 'cultural normalities regarding male and female life courses', the support systems and youth culture (Walther and Stauber 2002, 154).

Across the world, education policy-makers are looking for ways to overcome contemporary challenges that shape effective youth transitions in industrialised and postindustrial societies, as economic growth weakens and as demands for a more highly educated and skilled workforce get stronger. The key theme evident through a review of the youth transitions literature shows that it is young people with less education in lower status and lower paid occupations that are mostly disadvantaged in the labour market (Guarcello, Kovrova, and Lyon 2012, Fenton and Dermott 2006). This marginalisation has been attributed to their low level skills leading to a lack of flexibility, which makes them vulnerable to the ever-changing and expanding requirements of their occupations (Furlong and Cartmel 2004, 27). While precarious jobs may be a temporary fix for those from middle class backgrounds (for example during their university studies), for the less educated, reliance on low skilled, casualised and precarious employment may be their long-term outcome (Shildrick et al. 2010). These challenges have led policy makers to an increased reliance on employmentbased training (EBT) as a mechanism used for increasing retention and addressing skills shortages across many Organisation for Economic Co-operation and Development (OECD) countries. European policy-makers have explicitly called upon the VET sector to address significant rates of youth unemployment in Europe (European Commission 2011, Lisbon European Council 2000).

Although various apprenticeship systems exist in different countries, their major objective has focused on improving the labour market outcomes for young people, as emphasised by the OECD: 
'Well-designed vocational programmes, including apprenticeships which link work-based and classroom learning, equip young people with the skills that employers need, help to match young people to jobs, and form an important part of an effective skills strategy.' (OECD 2013, 9)

Germany, Switzerland and other systems characterised by so called 'employment logic' (Iannelli and Raffe 2007) have provided high quality apprenticeships which support effective school to work transitions. These high quality VET systems are characterised by the explicit and strong links between training, qualifications, skills and social partners (including trade unions and employers) (Bosch and Charest 2008). In these systems, apprenticeships also lead to a wide range of professions, crafts and skilled trades across a range of industries. These apprenticeships are considered high quality because they provide a high level of numeracy and literacy, and a wide range of general and company-specific skills. The high apprenticeship participation and retention rates are linked to the status of VET which is relatively high in relation to the academic curriculum. Nevertheless, even these systems struggle with providing equality of education. The OECD highlights that accessing high quality apprenticeships is often problematic for the most disadvantaged/disengaged youth (OECD 9 April 2014). Furthermore, there is evidence to suggest that coordinated market economies (like Germany) are more likely to be gender biased by investing in more 'firmspecific' skills which are not-gender neutral (Estevez-Abe 2005).

On the other hand, for countries where the 'education logic' system (Raffe 2012) is prevalent, like Australia, Canada and the United Kingdom (UK), the efficacy of EBT programs is even more challenging. Such systems are characterised by weaker links with industry and employers and are primarily driven by academic upper-secondary education with strong links to higher education. The range of occupations offered by the apprenticeship track is limited (compared to employment-logic systems); the apprenticeship track is often designed for entry into the traditional trades or services sector. There is greater advocacy for academic education in these systems, in terms of a valuable source of human capital. In these systems the challenge is to make apprenticeships attractive for students and employers by maintaining high standards of training and removing the barriers for employers who are taking apprentices on. So far Australia, the UK and Canada have struggled to establish 'high quality apprenticeships' as defined by the OECD.

In the UK, the 'modern apprenticeships' have been an important policy tool 'for the control of young people and as part of new legislation to keep them in some form of education 
or training to the age of 18' (Fuller and Unwin 2009, 1). The modern apprenticeships introduced in 1993 expanded the vocational qualifications available to apprentices, and allowed for 16-24 year olds to complete work-based training leading to a National Vocational Qualification (NVQ) in England, Wales and Northern Ireland, or a Scottish Vocational Qualification in Scotland. Through a series of government marketing initiatives the modern apprenticeships were successful in increasing the uptake of apprenticeship programs since 2005 - at the end of 2013 , there were 868,000 apprentices across the country, up from 172,600 in 2005 (Lerman 2014), with numbers growing in the broad vocational areas of healthcare, business administration and retail (Dion 2015). However, the past challenges of the UK system remained. International Labour Organisation and World Bank (2013) highlight discrepancy as to standards, competency measurement and delivery of apprenticeships across the United Kingdom. Furthermore, the issues of social exclusion within the apprenticeship sector in the UK have been a continuous problem. Penn (1998) argued that ethnic and gender exclusion was central to apprenticeship structures in both Britain and America and has been reinforced by historical and institutional contexts. The UK in particular has struggled with resolving the issue of underrepresentation and racial discrimination at an apprenticeship level. According to a 2009 report, 'there is a significant gender stereotyping by sector, while black and minority ethnic and disabled apprentices are underrepresented' (Learning and Skills Council 2009).

In Canada, regulations on apprenticeships vary between jurisdictions, but are traditionally trade-focused and male dominated. While most provinces introduced secondary school apprenticeship programmes, less than $10 \%$ of young people pursue apprenticeships across Canada, and completion rates are low despite rapid increase in new registrations in the past few years (Coe 2013, Lehmann, Taylor, and Wright 2014). Issues of public perception are also thought to frustrate uptake (Taylor, Lehmann, and Raykov 2014). Dion (2015) particularly noted the lack of federal government's involvement in Canada as a key factor inhibiting the expansion and acceptance of apprenticeships within the larger educational landscape, and the lack of a standardised training and assessment framework. The qualification system, which focuses on narrowly defined workplace roles and job-specific skills (Wheelahan, Buchanan \& Lu 2015), was also one of the major policy issues identified in relation to young school-based apprentices in Canada, with youth training being narrowly structured and students experiencing lack of support in expanding their qualifications (Lehmann, Taylor, and Wright 2014). Lehmann, Taylor, and Wright $(2014,61)$ emphasised 
that number of apprenticeships was not an answer when the experiences of these pathways were negative and those who needed support the most 'faced the most complex and uncertain routes and qualifications' (Keep 2009 cited in Lehmann, Taylor, and Wright 2014).

The above examples are illustrative of various challenges systems are facing in translating the employment-based programs into the effective youth transitions. The participation and completion rates, as well as meaningful transitions depend on the structural factors (e.g. structure of VET provision, curriculum, the links between education and industry and government support for these programs) and agency factors (e.g. educational experience, gender, health, socio-economic background and location). Taylor, Lehmann, and Raykov (2014), in their study on school-based apprentices in Canada, established that the traditional perception of the apprenticeship pathway as a linear path from school to trade is no longer appropriate in describing the movement from pathway to pathway within even the same trade area. They argue for greater flexibility of pathways, because young people tend to frequently change their aspirations and options. Young peoples' aspirations and motivations are important factors in selecting a career/trade pathway. Vaughan and Roberts (2007) suggest that young people have multiple and changing identities and their career options would need to fit within various possibilities for their lives. Their pathway option choices draw from their perceptions of themselves. These choices are obviously restricted or reinforced by their remoteness, opportunities, family and other factors.

\section{Skills requirement and youth transitions in Australia}

Australia's youth transition challenges are consistent with those internationally. Although its general unemployment rate is quite low at 6.2\% (ABS 2015), there are regional pockets of youth unemployment reaching 'crisis levels' with over $21 \%$ of young people without work (ABC 2015). Socio-economic status and rural location consistently influence education and employment outcomes in Australia. For young people who live in regional and rural Australia, access to a broad range of educational opportunities is restricted. For example, the rate of participation in VET and the qualification levels completed are lower when compared with those living in the metropolitan areas (Rothman et al. 2013). When combined with limited labour market options available in non-urban areas, rural location is one of the factors contributing to precarious youth transition outcomes.

The causes of difficult youth transitions and high youth unemployment in Australia are deeply connected with 'long-term permanent changes in the economy that have eliminated jobs traditionally undertaken by early school leavers' (Australian Human Rights Commission 
1989, 123). The Department of Employment in their report on skill shortages 2014-2015 informed that there were 'more than enough applicants with relevant qualifications' in any occupation and that skill shortages significantly declined in Australia in recent years (Department of Employment 2014). However, the technicians and trade workers remain in higher demand however the employers were not necessary convinced about the applicants suitability (Department of Employment 2014). In recent decades skill requirements have changed radically, and the labour market and economic situation in Australia requires new skills and new skills training options (WEF 2016; FYA 2016). Therefore, researchers argue that there is an urgent need to advance apprenticeship model of learning and teaching to find new ways of thinking about this concept and its practice (Billett 2015, Gonon 2015).

The purpose of this paper is to establish what is known about young people in Australia who take up school-based apprenticeships and traineeships, and to illustrate the participation of different social groups within SBATs. This paper investigates who is taking this pathway and the significance of the demographic characteristics of current cohorts as well as their selected fields of study. This analysis, combined with the existing research on apprenticeship programs, will enable a compelling picture of current trends in SBAT take up.

\section{School-based apprenticeships and traineeships in Australia}

Currently Australia's apprenticeship and traineeship framework is unique in the English-speaking world - only a handful of American states and Canadian provinces offer comparable systems, and there are no equivalent federal bodies and legislative arrangements that allow for comparable regulation. SBATs, representing a specific model of provision within the broader apprenticeship system, enable mainly senior secondary students the opportunity to undertake a paid apprenticeship or traineeship part-time, while also completing a senior school certificate. The capacity to undertake apprenticeships part-time is not common internationally (with the exception of Canada), and there are no VET in School (VETiS) equivalent frameworks.

A nationally unified entry level training system, which integrated state-based apprenticeships with Commonwealth-based traineeships, formed part of the government response to growing youth unemployment in the 1980s (Keating 1995). Following findings from the 1985 Kirby report of labour market programs (Kirby 1985), the model of employment-based training available within the apprenticeship model was extended with the introduction of traineeships. This expansion was in response to key concerns identified within the existing model of apprenticeships. Firstly, that existing provision was concentrated on a 
small number of traditional trade areas, many of which were in declining state-owned industries. A second and related concern was that the concentration of employment-based training in traditional trades meant the opportunities were limited for women and for those under-represented in traditional trade occupations (Knight 2012).

SBATs were first introduced in 1996 within the New Apprenticeship framework; they were seen as an alternative to full-time pathways and as a further stage in government attempts to broaden access to and participation in employment-based training, coinciding with a Commonwealth push to provide more VET in Schools (Knight 2012). This push was matched with funding incentives for secondary schools to establish training centres and a tax refund to apprentices and trainees of $50 \%$ for all education and training related expenses (Karmel and Mlotkowski 2008). SBATs gave young people the capacity to start a part-time apprenticeship or traineeship while still attending school. This allowed them to gain their senior school certificate - and, in certain situations, a university entrance score (an Australian Tertiary Admissions Rank - ATAR) - upon completion of Year 12, while earning an apprenticeship or traineeship certificate and receiving a part-time salary. Uptake of SBATs was initially slow, but grew rapidly from 6,100 in 2002 to 20,700 in 2008, dropping slightly to 19,000 in 2010 (Knight 2012) with the current enrolment of 21,000 (NCVER 2013). Australian-based studies of apprenticeship attrition and retention have found that personal or background factors, training factors, employment/industry factors, and structural/systembased factors all have an impact on apprenticeship retention (Bednarz 2014, Callan 2008, Volkoff and Jones 2007).

SBATs enable earlier and higher enrolments of young people into a training pathway in response to perceived industry need (Australian Apprentices Taskforce 2011) and a response to skill shortages (Karmel and Mlotkowski 2008). SBATs are high on the national and state-level policy agenda. Although there is no specific recruitment strategy for SBATs at schools, some jurisdictions provide incentives for specific equity groups. The Northern Territory, South Australia and Western Australia provide incentives for Indigenous groups. Commonwealth funded equity incentives also exist for apprentices and trainees from other nominated groups, including young people with disabilities, young people from droughtaffected regions, and there are living away from home allowances available for young people from remote areas. Available reports on SBATs generally present a positive experience by schools, apprentices, trainees and their employers (Smith and Wilson 2004, Helme et al. 2009). However, they also highlight the layered and demanding nature of SBAT 
requirements, student readiness and commitment, and the organisational complications involved in partnering various educational and employment stakeholders as issues to be addressed (Currie and McCollow 2002). Complications surrounding the requirements of SBATs and the need many students feel for a tertiary entrance score are further issues.

\section{Methods}

The data analysis was undertaken using statistical datasets obtained from the National Centre for Vocational Education Research (NCVER) which collects and stores Australian national VET data. The statistical analysis of two Combined Unit Record Files (CURFs) with data on 'Students and Courses- Students 2013' and 'VET in Schools - Students 2013' were obtained and analysed by researchers. These CURF files provided a national data for 15 to 19 year old apprenticeship and traineeship learners engaged in VET in Schools, including their gender, language background, location, socioeconomic status, occupation, field of education, school sector, employment status, and previous vocational qualification attainment. The datasets restricted the research to a combined analysis of both apprenticeships and traineeships, therefore the analysis and discussion referred to those two programs as one SBAT group.

\section{Findings}

\section{Demographics of SBAT learners}

In 2013, there were 21,676 SBAT learners, making up slightly less than one in ten (9\%) of all school students undertaking a vocational program in school. There were almost equal numbers of boys (51\%) and girls (49\%) undertaking SBATs across Australia. 
Figure 1 SBATs distribution according to SEIFA 2011

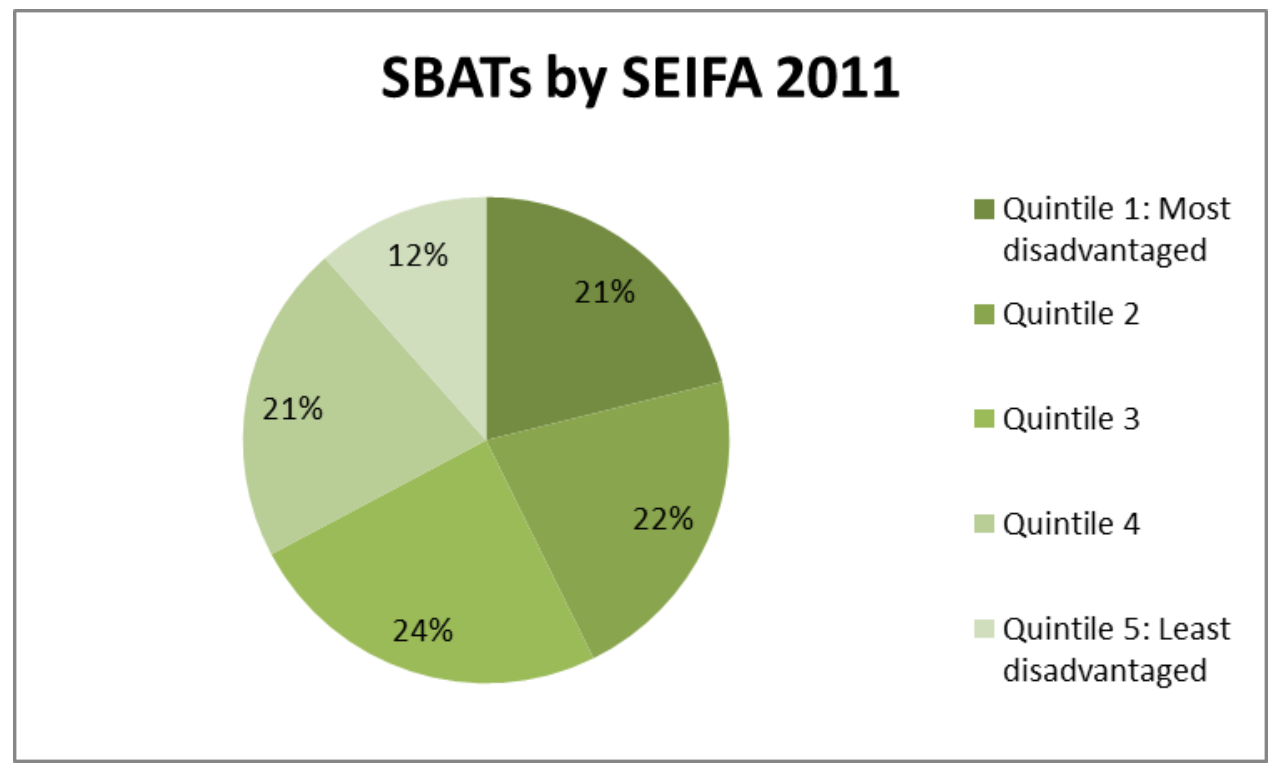

Figure 1 shows a fairly even distribution between the socio-economic groups with almost half (43\%) of these young people using an SBAT to complete school being from the two lowest quintiles of the Socioeconomic Index for Areas (SEIFA). There were more young women than young men from the lowest quintile enrolled in SBATs, while in the higher SES quintiles young men outnumbered their female counterparts. Datasets used for this analysis also included responses from Indigenous students with about 7.6\% of all SBATs declaring an Indigenous status. The majority of these students $(62.1 \%)$ came from two most disadvantaged background quintiles (see Figure 2).

Figure 2 SBATs distribution according to SEIFA 2011 of Indigenous students

\section{Indigenous SBATs by SEIFA 2011}

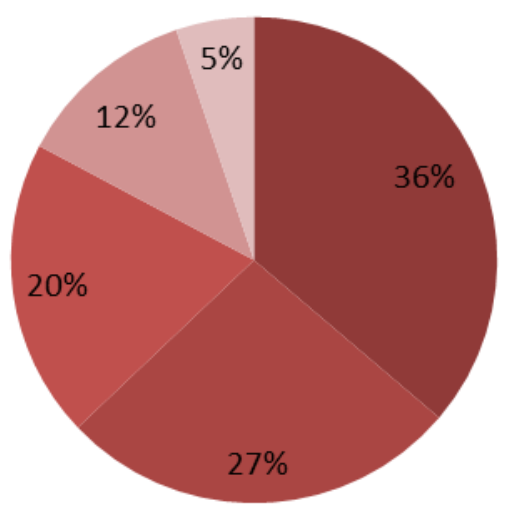

Quintile 1: Most disadvantaged

Quintile 2

Quintile 3

Quintile 4

Quintile 5: Least disadvantaged 
While there has been take-up of SBAT pathways across all three schooling sectors, the vast majority (78\%) of SBAT learners are in the government sector, with a further $10 \%$ in Catholic schools and 7\% in independent schools.

\section{Location}

The majority of SBATs are located in Queensland with over 12,660 students undertaking SBATs. Access to and take up of SBATs varies between urban and rural locations, with slightly more than half $(56 \%)$ of SBAT students living outside metropolitan areas. New South Wales and Queensland have the highest proportion of their SBAT learners living outside metropolitan areas (67\% and 61\% respectively). The balance between metropolitan and rural participation in SBATs is more even in Victoria and South Australia. The balance between the metropolitan and rural is skewed for Tasmania (72\% rural) and the Australian Capital Territory (93\% metropolitan), congruent with the geographic characteristics of those two jurisdictions. Western Australia, in contrast, has very little take-up of SBATs outside of Perth, with only $29 \%$ of SBAT learners living in rural areas.

If we look at where enrolments are high for SBATs, the list of local government areas reads as a list of Australia's disadvantaged communities and also as those regions facing high youth unemployment (ABS 2015). This is not unexpected as the research evidence confirms that socio-economically disadvantaged neighbourhoods influence children negatively in a social and educational sense (McLachlan, Gilfillan, and Gordon 2013).

\section{SBAT qualifications}

The vast majority $(72 \%)$ of SBAT learners were enrolled at Certificate III level. A further one in four $(24.2 \%)$ were enrolled in Certificate II level programs. 
Figure 3 SBATs distribution according to qualification level

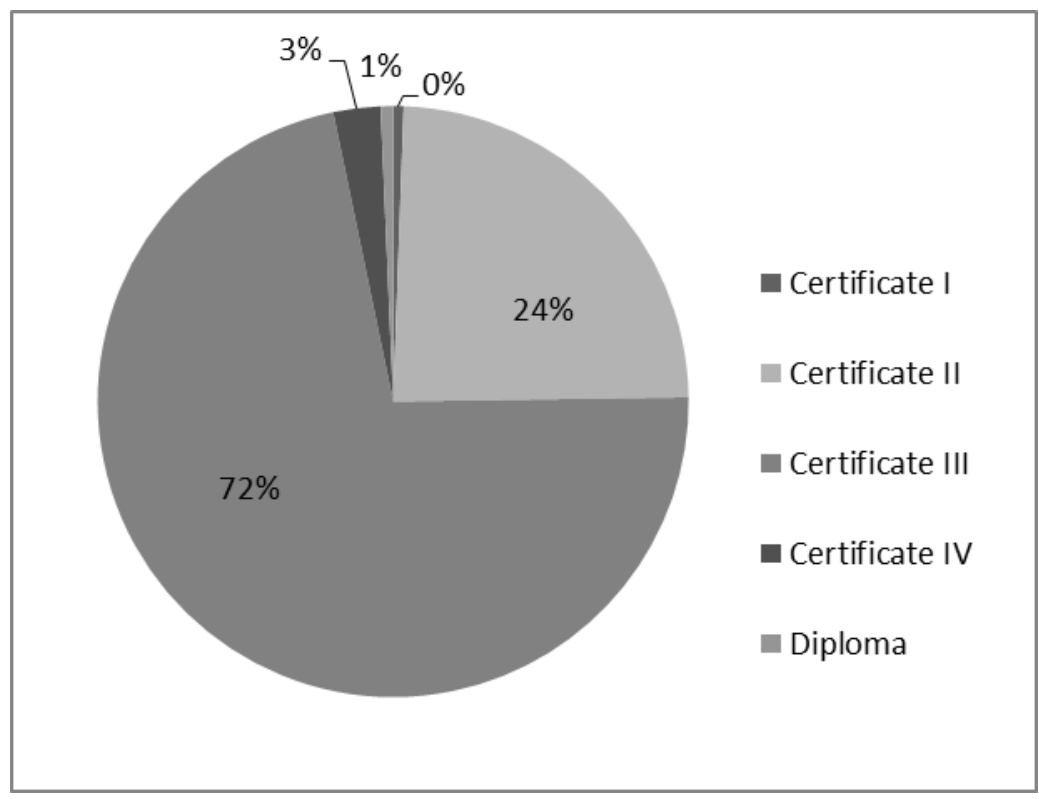

When we look at the relationship between the qualification levels and the socioeconomic status illustrated in Table 1 below we will see some interesting trends starting to appear. 
Table 1 Major qualifications levels distribution according to SEIFA

\begin{tabular}{|c|c|c|c|c|c|c|c|}
\hline \multicolumn{8}{|c|}{ Major Qualification Level } \\
\hline SEIFA 2011 & & $\begin{array}{c}\text { Certificate } \\
\text { | }\end{array}$ & $\begin{array}{c}\text { Certificate } \\
\text { II }\end{array}$ & $\begin{array}{c}\text { Certificate } \\
\text { III }\end{array}$ & $\begin{array}{l}\text { Certificate } \\
\text { IV }\end{array}$ & Diploma & Total* $^{*}$ \\
\hline \multirow{2}{*}{$\begin{array}{l}\text { Quintile 1: } \\
\text { Most } \\
\text { disadvantaged }\end{array}$} & Count & 9 & 1451 & 2949 & 104 & 25 & 4538 \\
\hline & $\%$ & $7.3 \%$ & $27.7 \%$ & $18.9 \%$ & $18.6 \%$ & $17.0 \%$ & $20.9 \%$ \\
\hline \multirow[t]{2}{*}{ Quintile 2} & Count & 7 & 1272 & 3244 & 90 & 26 & 4639 \\
\hline & $\%$ & $5.7 \%$ & $24.2 \%$ & $20.8 \%$ & $16.1 \%$ & $17.7 \%$ & $21.4 \%$ \\
\hline \multirow[t]{2}{*}{ Quintile 3} & Count & 14 & 1105 & 3980 & 130 & 36 & 5265 \\
\hline & $\%$ within & $11.4 \%$ & $21.1 \%$ & $25.5 \%$ & $23.3 \%$ & $24.5 \%$ & $24.3 \%$ \\
\hline \multirow[t]{2}{*}{ Quintile 4} & Count & 32 & 790 & 3529 & 174 & 39 & 4564 \\
\hline & $\%$ & $26.0 \%$ & $15.1 \%$ & $22.6 \%$ & $31.1 \%$ & $26.5 \%$ & $21.1 \%$ \\
\hline \multirow{2}{*}{$\begin{array}{l}\text { Quintile 5: } \\
\text { Least } \\
\text { disadvantaged }\end{array}$} & Count & 59 & 525 & 1814 & 58 & 20 & 2476 \\
\hline & $\%$ & $48.0 \%$ & $10.0 \%$ & $11.6 \%$ & $10.4 \%$ & $13.6 \%$ & $11.4 \%$ \\
\hline \multirow[t]{2}{*}{ Total } & Count & 123 & 5246 & 15601 & 559 & 147 & 21676 \\
\hline & $\%$ & $100.0 \%$ & $100.0 \%$ & $100.0 \%$ & $100.0 \%$ & $100.0 \%$ & $100.0 \%$ \\
\hline
\end{tabular}

*194 students did not disclose their SEIFA but were included in the total.

There are small numbers of SBAT students who undertake the lowest qualification level (Certificate I) but those who undertake these qualifications are predominantly young people from high socio-economic background. Table 1 illustrates that three-quarters of all those who are enrolled in Certificate I are from the two highest SEIFA Quintiles. Only ACT and SA are offering SBATs at this level with the majority enrolled being located in the ACT. Furthermore, over $50 \%$ of those enrolled in Certificate I undertake Engineering and related technologies, and almost $30 \%$ Food hospitality and personal services. It is possible that this pathway is used to test out specific occupations rather than as a pathway to full time apprenticeship.

The Certificate II level is predominantly undertaken by students from the two lowest quintiles - over $50 \%$ of all SBATs undertaking Certificate II. This is the most popular qualification level undertaken by the students from the lowest quintile with $28.2 \%$ enrolled in Cert II. This qualification level was also the most common among Indigenous Australians. It is clear that there is a strong link between the Certificate II uptake and socio-economic status 
(SES) as measured by SEIFA with the lowest participation rate at 10\% from the least disadvantaged group to $27.7 \%$ rate from the most disadvantaged.

The highest uptake of SBATs is at Certificate III, which corresponds with the typical level of qualification required to enter full trade apprenticeship after school. The take up has a bell-shaped curve across all the quintiles.

The Certificate IV is dominated by the medium and higher SES quintiles. This is the most popular qualification level for the young people from the second highest quintile with over $31 \%$ studying at this level.

\section{SBAT and industry sectors}

Fields of Education (FoE) selected by SBATs are illustrated in Table 2 Four fields of education dominate SBAT participation, making up three-quarters (75\%) of all SBAT enrolments: Management and commerce (26.5\%), Food hospitality and personal services (20.2\%), Society and culture (15.2\%) and Engineering and related technologies $(13.1 \%)$. The dominance of these four FoEs was fairly consistent across the different states and territories.

Table 2 Major Fields of Education distribution according to SEIFA

\begin{tabular}{|c|c|c|c|c|c|c|c|c|c|}
\hline \multicolumn{2}{|l|}{ SEIFA 2011} & $\begin{array}{c}\text { Management } \\
\text { and } \\
\text { commerce }\end{array}$ & $\begin{array}{c}\text { Food } \\
\text { hospitality } \\
\text { and } \\
\text { personal } \\
\text { services }\end{array}$ & $\begin{array}{l}\text { Society } \\
\text { and } \\
\text { culture }\end{array}$ & $\begin{array}{l}\text { Engineering } \\
\text { and related } \\
\text { technologies }\end{array}$ & $\begin{array}{l}\text { Agriculture } \\
\text { environment } \\
\text { and related } \\
\text { studies }\end{array}$ & $\begin{array}{c}\text { Architecture } \\
\text { and } \\
\text { building }\end{array}$ & $\begin{array}{l}\text { Other } \\
\text { fields }\end{array}$ & Total $^{*}$ \\
\hline \multirow{3}{*}{$\begin{array}{l}\text { Quintile 1: } \\
\text { Most } \\
\text { disadvantaged }\end{array}$} & Count & 1378 & 898 & 657 & 567 & 243 & 245 & 550 & 4538 \\
\hline & $\begin{array}{l}\% \\
\text { within } \\
\text { MFoE }\end{array}$ & $24 \%$ & $20.5 \%$ & $19.9 \%$ & $20 \%$ & $26.4 \%$ & $17.3 \%$ & $17.9 \%$ & $20.9 \%$ \\
\hline & $\begin{array}{l}\% \\
\text { within } \\
\text { SEIFA }\end{array}$ & $30.4 \%$ & $19.8 \%$ & $14.5 \%$ & $12.5 \%$ & $5.4 \%$ & $5.4 \%$ & $12 \%$ & $100 \%$ \\
\hline \multirow[t]{3}{*}{ Quintile 2} & Count & 1204 & 927 & 605 & 728 & 303 & 308 & 564 & 4639 \\
\hline & $\begin{array}{l}\% \\
\text { within } \\
\text { MFoE }\end{array}$ & $21 \%$ & $21.1 \%$ & $18.3 \%$ & $25.6 \%$ & $32.9 \%$ & $21.7 \%$ & $18.4 \%$ & $21.4 \%$ \\
\hline & $\begin{array}{l}\% \\
\text { within } \\
\text { SEIFA }\end{array}$ & $26 \%$ & $20 \%$ & $13 \%$ & $15.7 \%$ & $6.5 \%$ & $6.6 \%$ & $12.2 \%$ & $100 \%$ \\
\hline \multirow[t]{3}{*}{ Quintile 3} & Count & 1291 & 1057 & 862 & 700 & 242 & 360 & 753 & 5265 \\
\hline & $\begin{array}{l}\% \\
\text { within } \\
\text { MFoE }\end{array}$ & $22.5 \%$ & 24.1 & $26.1 \%$ & $24.6 \%$ & $26.3 \%$ & $25.4 \%$ & $24.5 \%$ & $24.3 \%$ \\
\hline & $\begin{array}{l}\% \\
\text { within } \\
\text { SEIFA }\end{array}$ & $24.5 \%$ & $20.1 \%$ & $16.4 \%$ & $13.3 \%$ & $4.6 \%$ & $6.8 \%$ & $14.3 \%$ & $100 \%$ \\
\hline \multirow[t]{2}{*}{ Quintile 4} & Count & 1173 & 961 & 718 & 554 & 86 & 296 & 776 & 4564 \\
\hline & $\begin{array}{l}\% \\
\text { within } \\
\text { MFoE }\end{array}$ & $20.4 \%$ & 21.9 & $21.8 \%$ & $19.5 \%$ & $9.3 \%$ & $20.9 \%$ & $25.3 \%$ & $21.1 \%$ \\
\hline
\end{tabular}




\begin{tabular}{|c|c|c|c|c|c|c|c|c|c|}
\hline & $\begin{array}{l}\text { \% } \\
\text { within } \\
\text { SEIFA }\end{array}$ & $25.7 \%$ & $21 \%$ & $15.7 \%$ & $12.1 \%$ & $1.9 \%$ & $5.4 \%$ & $18.2 \%$ & $100 \%$ \\
\hline \multirow{3}{*}{$\begin{array}{l}\text { Quintile 5: } \\
\text { Least } \\
\text { disadvantaged }\end{array}$} & Count & 629 & 509 & 431 & 277 & 36 & 196 & 398 & 2476 \\
\hline & $\begin{array}{l}\% \\
\text { within } \\
\text { MFoE }\end{array}$ & $10.9 \%$ & 11.6 & $13.1 \%$ & $9.8 \%$ & $3.9 \%$ & $13.8 \%$ & $12.9 \%$ & $11.4 \%$ \\
\hline & $\begin{array}{l}\% \\
\text { within } \\
\text { SEIFA }\end{array}$ & $25.4 \%$ & $20.6 \%$ & $17.4 \%$ & $11.2 \%$ & $1.5 \%$ & $7.9 \%$ & $16 \%$ & $100 \%$ \\
\hline \multirow[t]{2}{*}{ Total } & Count & 5747 & 4385 & 3301 & 2840 & 920 & 1418 & 3065 & 21676 \\
\hline & $\%$ & $100 \%$ & $100 \%$ & $100 \%$ & $100 \%$ & $100 \%$ & $100 \%$ & $100 \%$ & $100 \%$ \\
\hline
\end{tabular}

*194 students did not disclose their SEIFA but were included in the total.

The Management and commence field was dominated by enrolments in certificates in retail or business with almost half of the enrolled students $(42.5 \%)$ undertaking Certificate II. Certificate II in Retail or Retail Services had the highest uptake with 50\% enrolled. This field of study was popular especially among the students from the lowest quintile who comprise over a quarter of all enrolled in Management and commerce. When we look at the distribution of all students from the lowest quintile across all sectors, over $30 \%$ study this field. This is the top selected field of study for the two lowest SES SBATs. Only $10 \%$ of all management and commerce students came from the top SEIFA quintile while a quarter came from the lowest quintile.

The Food hospitality and personal services includes hairdressing, tourism, hospitality and events with the majority of enrolled undertaking Certificate III (81\%). The participation rates from all SES groups were spread equally among the four quintile groups with the exception of the top quintile with only $11.6 \%$ of all enrolled.

A large number (85\%) of all enrolled in the Society and culture took up Cert III level courses which included a popular Sport and recreation. This field of study was dominated by the young people from the middle quintile with over a quarter of students from this group.

The quarter of SBATs in Engineering (automotive industry retail, service and repair; metal and engineering) did Certificate II with a majority of students coming from second and third quintile.

Information technology and Creative arts fields had the highest representation from the two top quintiles where almost half $(46.8 \%)$ of all students enrolled in IT and with over $40 \%$ of all students in Creative arts. 
Table 3 Major Fields of Education (MFoE) distribution for Indigenous SBATs

\begin{tabular}{|c|c|c|c|c|c|c|c|c|c|}
\hline Fields of Stuc & & $\begin{array}{l}\text { Management } \\
\text { and } \\
\text { commerce }\end{array}$ & $\begin{array}{l}\text { Food } \\
\text { hospitality } \\
\text { and } \\
\text { personal }\end{array}$ & $\begin{array}{l}\text { Society } \\
\text { and } \\
\text { culture }\end{array}$ & $\begin{array}{l}\text { Engineering } \\
\text { and related }\end{array}$ & $\begin{array}{l}\text { Agriculture } \\
\text { environment } \\
\text { and related }\end{array}$ & $\begin{array}{c}\text { Architecture } \\
\text { and } \\
\text { building }\end{array}$ & $\begin{array}{l}\text { Other } \\
\text { Fields }\end{array}$ & Total $^{*}$ \\
\hline Indigenous & Count & 596 & 246 & 251 & 139 & 82 & 80 & 246 & 1640 \\
\hline & $\%$ & $36.3 \%$ & $15 \%$ & $15.3 \%$ & $8.5 \%$ & $5 \%$ & $4.9 \%$ & $15 \%$ & $100 \%$ \\
\hline
\end{tabular}

Indigenous students' selection of the field of study followed a similar pattern to the general population with the majority enrolled in Management and commerce (36.3\%) and Food hospitality and personal services (15.0\%). However there were relatively more Indigenous students in Management and commerce, and many fewer of them undertaking Engineering - only $8.5 \%$ compared to $13.4 \%$ for the non-Indigenous population.

Figure 4 Fields of education (FoE) distributed by gender

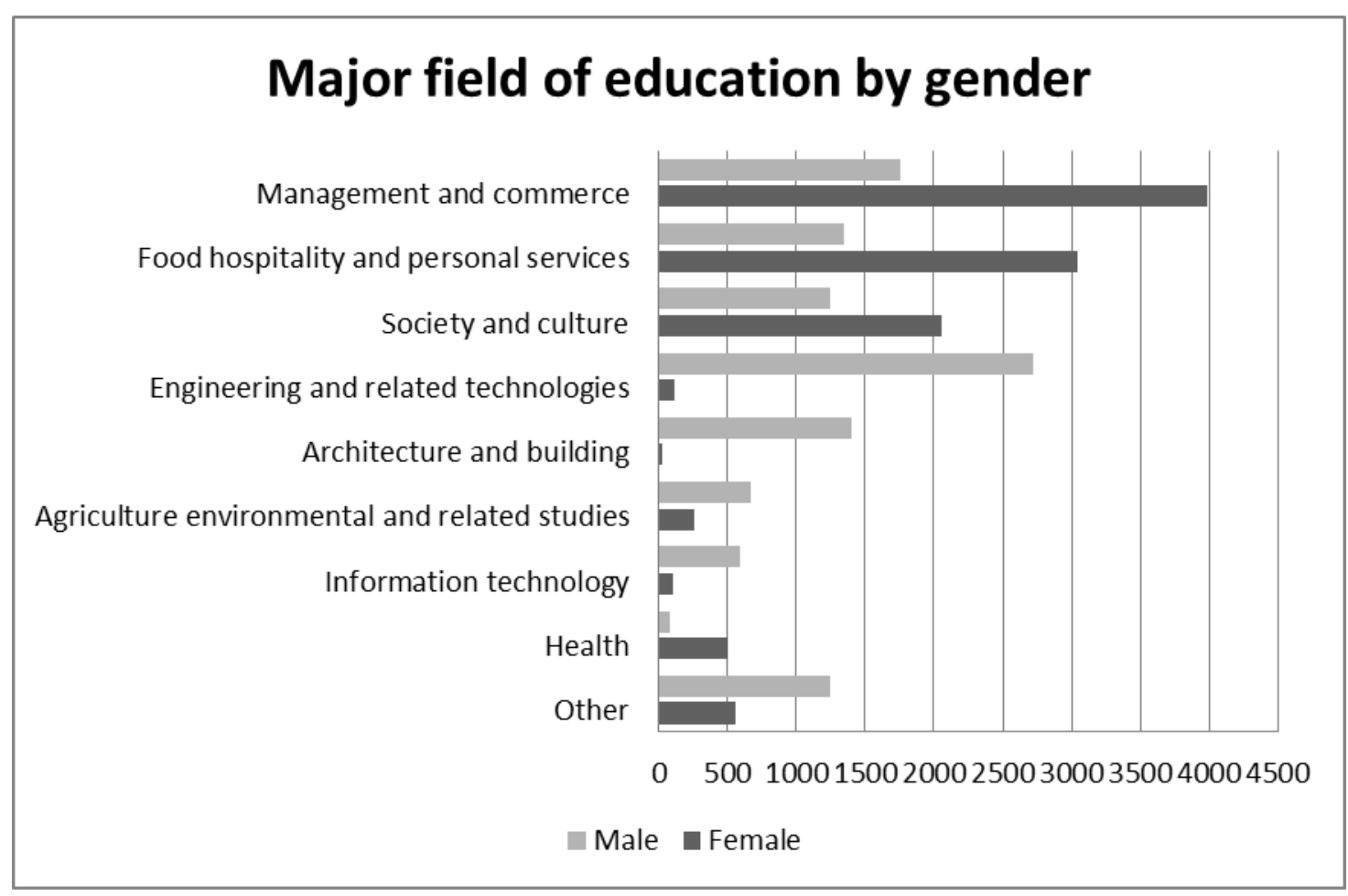

The take-up of SBATs in the various FoEs is very much gender-specific. Engineering, architecture and IT were dominated by male students while female students were more likely to undertake a management and commerce or hospitality SBAT. There were also FoE differences between metropolitan and rural areas. SBATs in rural areas were more likely than their metropolitan peers to be enrolled in architecture, engineering and health related fields, 
while metropolitan SBATs were more likely than those in rural areas to enrolled in education and information technology fields.

\section{Discussion}

Current Australian SBAT policy discourse reinforces a stereotypical SBAT learner as a young man from regional Queensland undertaking Certificate III in Engineering or related technologies, or a young woman training in Hairdressing or Child-care services. However this stereotype is hiding other features which are problematic and related to socio-economic disadvantage, qualification levels and gender participation.

The take-up of SBATs by gender seems to be quite equal in distribution however the various fields of study show significant differences in participation depending on gender, with young men more likely to be doing an engineering SBAT and young women more likely to be undertaking a management and commerce or hospitality SBAT. The service sector SBAT pathway undertaken by the majority of female students is more likely to lead to poorer career prospects and lower pay. Nevertheless, female Australian students continue to select the traditional, gendered educational pathways. One of the reasons for this maybe the fact that apprenticeships are in themselves more likely to be gender-segregating because of a greater employer involvement in training and their firm-specific focus on training (Estevez-Abe 2005). Women are more likely to invest in general skills which are portable rather than attached to one employer in a specific vocational craft which restrict skills portability, Estevez-Abe (2005) argues. These SBAT pathway selections mirror the highly gendersegregated nature of the Australian labour force which in turn facilitates wage discrimination, so it is worrying that already at school level these segregated pathways are reinforced. Just like the UK (Fuller and Unwin 2013), Australian participation data suggests current approaches to employment-based training for young people are doing little to address gender imbalances in key in-demand and growth occupations. School-based gender-informed career advice, which increases students' knowledge of job markets, can be beneficial for career choices for women (Butler, Clarke \& Simon 2014; Simon \& Clarke 2016).

While the distribution of socio-economic groups participating in SBAT it seems to be quite comparable in general, the difference between these groups becomes apparent in the analysis of these groups against the qualifications levels. The lowest qualification levelCertificate I - is, surprisingly, undertaken largely by the students from two highest SEIFA quintiles. Such low qualification levels within SBAT have very limited potential to lead to entry to full-time apprenticeships post-school as they lack significant industry exposure and 
industry is concerned about their credibility (Clarke, 2012). It may be assumed then the Certificate I pathway within the SBAT is selected by students who can afford to test out specific occupations rather than to use it as a pathway to full time apprenticeship, or by students with special-needs. The students from higher SES would be expected to get more financial support and therefore would be more flexible in changing their field of education post-school. However, it is difficult to understand why students would take up a Certificate I level qualification within SBAT as it has very limited recognition within the industry.

The significant and problematic trend can be seen at the Certificate II level, which is also seen as a weak pathway to full time apprenticeship. It is disturbing that this qualification level is predominantly (over 50\%) undertaken by students from the two lowest quintiles. There is a strong link between the Certificate II uptake and SES. This is a worrying trend as this qualification level has a very poor perception among employers. The industry argues that although the apprentices have reached stage two of their theoretical learning they have minimal industry experience (Clarke 2012), therefore their prospects of securing a meaningful and long-term employment in a chosen field are poor. As such, the majority of the already disadvantaged young people who undertake Certificate II are streamlined in a pathway that may not lead to the improved socio-economic outcomes. The kids who take up these lower qualification levels become disadvantaged in the labour market from the start as this pathway thwarts their access to further education, prepares them for less skilled occupations and undermines their employment perspective as employers are more likely to rely on higher levels of qualifications as an indication of applicant's abilities in their selection for jobs.

Another issue identified in this study shows that four fields of study enjoy the most popularity among SBATs: Management and commerce (26.5\%), Food hospitality and personal services (20.2\%), Society and culture (15.2\%) and Engineering and related technologies (13.1\%). Almost 50\% of all SBATs, including the majority of Indigenous students, rely on two fields of study which are: Management and commerce and Hospitality and personal services which include common occupations such as retail, hairdressing and hospitality. It raises some concerns about the efficacy of those fields in enabling transition to sustainable and secure post-school employment and employment-based training. Many graduates do not end up in jobs related to their field of study, suggesting that these fields do not lead directly to employment. For example, only $20 \%$ of Hospitality graduates worked in their intended occupation in 2009 (Creaser 2010). Although Management and commerce graduates were found to be able to enter further studies, Wheelahan, Buchanan, and Yu 
(2015) found that this pathway was ineffective in supporting social mobility for students from low socio-economic backgrounds. Therefore the dominance of these two fields of study in the low-level qualifications at the school level has serious implications for the educational, labour market and social outcomes. It is even more troubling when considering high participation of Indigenous students in these fields of study, because Indigenous students have fewer options available to them and are more dependent on this pathway (Helme and Hill 2004). Low qualifications in these industries do not facilitate stronger employment outcomes, so these young people will face difficulties in progressing from education to work. The research shows that Indigenous people, people with a disability, and rural and remote Australians had good employment outcomes upon completing full time apprenticeships (Bednarz 2014). However there is no data available to assess the effectiveness of SBATs on these equity groups' labour market outcomes.

Previous work (Clarke 2013, 2012) has highlighted the tension for schools between providing access to vocational curriculum that is of relevance and interest to their students and promoting enrolment in vocational curriculum that has currency and value in the local labour market. Klatt et al. (2016) also established that students' choices of VET pathways are based on short-term considerations and tend to take an optimistic view about their future. They are often based on negative experiences of schooling and self-assessment as 'bad' learners. The questions therefore need to be asked about the real purpose of these SBAT pathways and the motivations behind the selection and offer of some low qualifications in these fields of study by the schools.

\section{Conclusions}

This paper identified several weaknesses of a current SBAT model which suggests that SBAT, and all other VET in School programs, need re-thinking in terms of its purpose, curriculum and provision. We agree with Wheelahan \& Moodie (2011) that weaknesses in the Australian VET sector have led to underuse of education, skills and qualifications in some circumstances and under-education, under-skilling and under-qualification in others.

What has been observed is that the SBAT pathway is serving several purposes, including as a pathway to school completion (and engagement), and as a pathway to employment. These pathways are most frequently being used in communities confronting the challenges of high youth unemployment. The emphasis on 'employability' as the core purpose of these school based training programs is highly problematic and misleading in the context of the Australian system. These programs should be regarded as 'industry tasting' and 
an opportunity to explore core characteristics of occupations. These occupational 'explorations' should be backed by a strong career planning component, as well as strong numeracy and literacy education.

There are also significant implications of this study for future research as it confirms that 'education logic' systems like Australia are still struggling with reconciling the meaning and purpose of vocational education and training. There is a lack of clear policy objectives assigned to SBATs or measurements of long-term benefits for learners and employers. Furthermore, limited empirical and theoretical work exists which examines the efficacy of SBATs in building solid skill foundations for employment. This lack of evidence is particularly problematic in light of declining training completion rates (NCVER 2015) and the need for evidence based policy.

There needs to be an acknowledgement from policy-makers that the traditional school's structures, processes and tasks have evolved to serve diverse range of students facing an unpredictable and fast changing labour market. Researchers argue that there is an urgent need to advance the apprenticeship model of learning and teaching, and to find new ways of thinking about this concept and its practice in supporting the development of a skilled workforce (Gonon 2015, Billett 2015). In this context it is important to bear in mind that the funding, program delivery and education policy-making requires a new approach.

This study suggest that there is a need to develop a long term longitudinal quantitative and qualitative study which would focus on policy, experiences and post-school destinations of SBAT learners, to establish the extent to which SBATs offer a meaningful mechanism for addressing skills shortages and providing strong school to work pathways for young people, especially those from disadvantaged backgrounds. It should gather empirical evidence on the strengths and weaknesses of the current SBAT model, from the perspective of learners, employers and schools. Such research would generate a strong evidence base for informing policy and practice about the structural, motivational and opportunity barriers for SBAT learners and SBAT employers. Understanding the role that this school-based model can play in the broader employment-based training landscape is important, given that some estimates place the overall current apprenticeship completion rate at little more than 50 per cent (Curtis and McMillan 2008, NCVER 2015).

\section{Bibliography}


ABC. 2015. "Youth unemployment at 'crisis' levels in Victoria, regional areas worst affected." $A B C$ News (4 July 2015). doi: http://www.abc.net.au/news/2015-07-04/youthunemployment-at-crisis-levels-in-victoria/6589464.

ABS. 2015. "Media release: Australia's unemployment rate at 6.2 per cent in September 2015." Labour Force, Australia. doi: http://www.abs.gov.au/ausstats\%5Cabs@.nsf/mediareleasesbyCatalogue/46DFE12FC DB783D9CA256B740082AA6C?Opendocument.

Australian Apprentices Taskforce. 2011. A shared responsibility. Apprenticeships for the 21st Century. In Apprenticeships for the 21st Century Expert Panel Paper: Commonwealth of Australia.

Australian Human Rights Commission. 1989. Report of the National Inquiry into Youth Homelessness. Canberra.

Bednarz, A. 2014. Understanding the non-completion of apprentices. Adelaide: NCVER.

Billett, S. 2015. "Two distinct conceptions of apprenticeship." In Architectures for apprenticeship: Achieving economic and social goals, edited by Erica Smith, Philipp Gonon and Annette Foley, 17-20. Ballarat: Australian Scholarly Publishing.

Birmingham, S. 2015. Ballarat to pilot technology education initiative. Canberra: The Department of Education and Training Media Centre.

Bosch, G, and J. Charest. 2008. "Vocational training and the labour market in liberal and coordinated economies." Industrial Relations Journal 39 (5):428-447.

Butler, E., Clarke, K. and Simon, L. (2014), "Hard hats, robots and lab coats: broadening the career options of young women", Report prepared by WAVE for economic Security 4 Women, Sydney.

Callan, V. J. 2008. Accelerated apprenticeships: apprentice, employer and teaching staff perceptions. Adelaide: NCVER.

Clarke, K. 2012. Entry to Vocations: The efficacy of VET in schools. Adelaide: NCVER.

Clarke, K. 2013. Entry to the vocations: strengthening VET in Schools. Adelaide: NCVER.

COAG. 2008. National Education Agreement Canberra: COAG.

Coe, P. J. 2013. "Apprenticeship Programme Requirements and Apprenticeship Completion Rates in Canada." Journal of Vocational Education and Training 65 (4):575-605.

Creaser, M. 2010. "Job prospects for VET students." 2010 ACPET National Conference, Melbourne.

Currie, W., and J. McCollow. 2002. Vocational education and training in schools: Enhancing student career options. Canberra: AEU.

Curtis, D. D., and J. McMillan. 2008. School Non-Completers: Profiles and Initial Destinations. Longitudinal Surveys of Australian Youth. Research Report 54.

Department of Employment. 2014. Skill shortages. Statistical summary 2014-15. Canberra.

Dion, C. 2015. Apprenticeship in International Perspective: Points of Contract with Ontario. In Issues paper No. 21. Toronto: The Higher Education Quality Council of Ontario.

Estevez-Abe, M. 2005. "Gender Bias in Skills and Social Policies: The Varieties of Capitalism Perspective on Sex Segregation." Social Politics: International Studies in Gender, State and Society (2):180. 
European Commission. 2011. Attitudes towards vocational education and training. In Special Eurobarometer 369.

FYA Foundation for Young Australians. (2016). The new basics: Big data reveals the skills young people need for the New Work Order. fya.org.au.]Fenton, S., and E. Dermott. 2006. "Fragmented careers." Work, Employment and Society 20 (2):205-221.

Fuller, A. and L. Unwin. 2009. "Change and continuity in apprenticeship: the resilience of a model of learning." Journal of Education and Work 22 (5):405-416. doi: 10.1080/13639080903454043.

Fuller, A. and L. Unwin. 2013. "Gender Segretation, Apprenticeship, and the Raising of the Participation Age in England: are Young Women at a Disadvantage?" The Centre for Learning and Life Chances in Knowledge Economies and Societies Research Paper 44.

Furlong, A. and F. Cartmel. 2004. Vulnerable young men in fragile labour markets: employment, unemployment and the search for long-term security. York: Joseph Rowntree Foundation.

Gallie, D., and S. Paugam. 2000. Welfare Regimes and the Experience of Unemployment in Europe. Oxford: Oxford University Press.

Gonon, P.. 2015. "Conference Opening Speech." The International Network on Innovative Apprenticeship, Ballarat, Australia.

Guarcello, L., I. Kovrova, and S. Lyon. 2012. Youth disadvantage in the labour market: Empirical evidence from nine developing countries. edited by Working paper. Rome: Understanding Children's Work (UCW) Programme.

Helme, S., and A. Hill. 2004. "Indigenous students' experiences of Vocational Education and Training in Schools programs: Insights for developing good practice." Australian Association for Research in Education Conference, Melbourne.

Helme, S., R. Teese, N. Dulfer, L. Robinson, and T. Jones. 2009. Provision, participation and achievement: A study of the western metropolitan region. Unpublished draft report of the Centre for Post-compulsory Education and Lifelong Learning.

Iannelli, C., and D. Raffe. 2007. "Vocational Upper-Secondary Education and the Transition from School." European Sociological Review 23 (1):49-63. doi: 10.1093/esr/jc1019.

International Labour Organisation and World Bank. 2013. Towards a Model Apprenticeship Framework: A Comparative Analysis of National Apprenticeship Systems. Geneva: International Labour Organisation.

Johnston, M., and A. Smethurst. 2014. Denis Napthine pledges more work experience for struggling schoolkids. In Herald Sun. Melbourne: News Corp.

Karmel, T., and P. Mlotkowski. 2008. School-based apprenticeships and traineeships. Adelaide: NCVER.

Keating, J. 1995. Introducing vocational education. Carlton, Vic: Curriculum Corporation (Australia).

Kirby, P, Australia Committee of Inquiry into Labour Market Programs1985, Report of the Committee of Inquiry into Labour Market Programs [Kirby report], Australian Government Publishing Service, Canberra. 
Klatt, M., J. Polesel, N. Dulfer, K. Starr, and D. Blake. 2016. VET Partnerships for youth engagement in education and work. Report for the Industry Partners. Linkage Project LP120200272. Melbourne: Centre for Vocational and Educational Policy, the University of Melbourne.

Knight, B. 2012. Evolution of Apprenticeships and Traineeships in Australia: An Unfinished History. Occasional Paper. National Centre for Vocational Education Research (NCVER).

Learning and Skills Council. 2009. Addressing inequality in apprenticeships: learners' views. London: Learning and Skills Council.

Lehmann, W. A. Taylor, and L. Wright. 2014. "Youth Apprenticeships in Canada: On Their Inferior Status Despite Skilled Labour Shortages." Journal of Vocational Education and Training 66 (4):572-589.

Lerman, R. I. 2014. Expanding Apprenticeship Training in Canada: Perspectives from International Experience. Toronto, Canada: Canadian Council of Chief Executives.

Ley, S. 2014, 1 July. Current state of VET reform in Australia. Canberra: The Department of Education and Training Media Centre.

Lisbon European Council. 2000. Presidency Conclusions.

McLachlan, R. , G. Gilfillan, and J. Gordon. 2013. Deep and persistent disadvantage in Australia. Canberra: Productivity Commission Staff Working Paper.

NCVER. 2013. Combined Unit Record File. VET in Schools - Students 2013. Adelaide, SA: National Centre for Vocational Education Research.

NCVER. 2015. "Training completion rate declines for young people." https://www.ncver.edu.au. Adelaide, SA: National Centre for Vocational Education Research.

OECD. 9 April 2014. "G20-OECD-EC Conference on Quality Apprenticeships for Giving Youth a Better Start in the Labour Market." OECD Conference Centre, Paris.

OECD. 2013. Action Plan for Youth (Report prepared for Meeting of the Council at Ministerial Level, May 2013). Paris: OECD.

Penn, R. 1998. "Social exclusion and Modern Apprenticeships: a comparison of Britain and the USA." Journal of Vocational Education and Training 50 (2):259-275.

Pohl, A., and A. Walther. 2007. "Activating the disadvantaged. Variations in addressing youth transitions acrossEurope." International Journal for Lifelong Education 26 (5):533-553.

Queensland Government. 2014. Great skills. Real opportunities. The Queensland Government reform action plan for further education and training. Edited by Training and Employment Department of Education.

Raffe, D. 2003. "Pathways Linking Education and Work: A Review of Concepts, Research, and Policy Debates." Journal of Youth Studies 6 (1):3-19. doi: 10.1080/1367626032000068136.

Raffe, D. 2012. "Explaining national differences in education-work transitions: 20 years of research on transition systems." European Network on Transitions in Youth: 20th Annual Workshop, Nijmegen, 5-8 September 2012. 
Rothman, S., C. Shah, C. Underwood, Julie McMillan, and Justin Brown. 2013. National Report on Social Equity in VET 2013. Melbourne: Australian Council for Educational Research.

Shildrick, T., R. MacDonald, C. Webster, and K. Garthwaite. 2010. The low pay, no pay cycle: Understanding recurrent poverty. York, United Kingdom: The Joseph Rowntree Foundation.

Simon, L. and Clarke, K. 2016 "Apprenticeships should work for women too!", Education + Training 58 (6): pp. 578 - 596.

Smith, E., and L. Wilson. 2004. "School-based apprenticeships and traineeships in Australia." Education + Training 46 (2): 64-74. doi: doi:10.1108/00400910410525243.

Standing, G. 2011. The precariat: the new dangerous class: Bloomsbury Acad.

Taylor, A., W. Lehmann, and M. Raykov. 2014. "“Should I stay or should I go?” Exploring high school apprentices' pathways." Journal of Education and Work: 1-25. doi: 10.1080/13639080.2014.887199.

Vaughan, K., and J. Roberts. 2007. "Developing a 'productive' account of young people's transition perspectives." Journal of Education and Work 20 (2): 91-105. doi: 10.1080/13639080701314621.

Verdier, E. 10-12 September, 2009. "European Lifelong Learning Strategy and Diversity of National Devices." The European Consortium for Political Research Conference, Potsdam, Germany.

Volkoff, V., and T. Jones. 2007. "Analysis of factors contributing to apprenticeship and traineeship completion." Melbourne: Office of Training and Tertiary Education.

Walther, A., and B. Stauber. 2002. Misleading trajectories: integration policies for young adults in Europe?, Publication of the European Group for Integrated Social Research (EGRIS). Wiesbaden: Springer Fachmedien.

Wheelahan, L., J. Buchanan, and S. Yu. 2015. Linking qualifications and the labour market through capabilities and vocational streams. Adelaide: NCVER.

Wheelahan, L., and G. Moody. 2011. Rethinking skills in vocational education and training: from competencies to capabilities. Sydney: NSW Board of Vocational Education and Training.

WEF World Economic Forum. (2016). The future of jobs: Employment, skills and workforce strategy for the Fourth Industrial Revolution. Geneva, World Economic Forum. 


\section{University Library}

\section{- M M N E R VA A gateway to Melbourne's research publications}

Minerva Access is the Institutional Repository of The University of Melbourne

Author/s:

Klatt, M;Clarke, K;Dulfer, N

Title:

Working their way to school completion: a snapshot of School-based Apprenticeships and Traineeships for young Australians

Date:

2017-01-01

Citation:

Klatt, M., Clarke, K. \& Dulfer, N. (2017). Working their way to school completion: a snapshot of School-based Apprenticeships and Traineeships for young Australians. JOURNAL OF VOCATIONAL EDUCATION AND TRAINING, 69 (4), pp.473-494. https:// doi.org/10.1080/13636820.2017.1326161.

Persistent Link:

http://hdl.handle.net/11343/243056 